\title{
Inventaire des recherches sur l'enseignement supérieur au Canada
}

\author{
L.F. Michaud, J.F. Houwing *
}

The Association of Universities and Colleges of Canada gathers information on research work in progress regarding higher education in Canada.

L'Association des Universités et Collèges du Canada a entrepris de recueillir des renseignements sur les recherches en cours sur l'enseignement supérieur au Canada.

This information, including descriptions of unpublished dissertations, is regularly published in STOA under the headings indicated below. / Nous présenterons les renseignements, y compris des résumés de thèses, par sujets, à l'aide des rubriques suivantes.

I - University Government / Administration universitaire

II - University Finance / Finances universitaires

III - University and the Economy / L'université et l'économie

IV - Curriculum and Teaching / Programme d'études et enseignement

V - Professional Education / Enseignement professionnel

VI - Admissions / Inscriptions

VII - Evaluating and Grading / Evaluation et classement

VIII - Research and Scholarship / Recherche et études

IX - Student and Student Services / L'étudiant et les services aux étudiants

$\mathrm{X}$ - The Professor and Conditions of work /

Le professeur et les conditions de travail XI - Non-Degree Granting Institutions/Établissements qui ne confèrent pas de grades

* Lucien Michaud, directeur de la recherche ,A.U.C.C.

J.F. Houwing, Research Officer, A.U.C.C. 
Pour chaque projet les renseignements se lisent d'après le code suivant / Each project's information is coded as follows :

1. Project Title / Titre du projet

2. Objectives / Buts

3. Method / Méthode

4. Principal investigator (s) / Responsable (s)

5. Other research associates / Autres chercheurs

6. Institution where project is located / Institution où le projet est réalisé

7. Supporting body / Subventionné par

8. Date of Commencement / Date du début

9. Date of Completion / Date de la fin

10. Results obtained from... / Les résultats obtenus de...

to be published in... / publiés dans...

11. Dissertation or report abstract / Résumé de thèse ou rapport

\section{I - University Government}

1. A History of the Association of Universities and Colleges of Canada.

2. To examine the role played by the A.U.C.C. since its establishment as the Conference of Canadian Universities in 1911, with special reference to the way in which it has influenced the social and intellectual development of Canada.

3. Examination and analysis of all primary source material available at the A.U.C.C. office in Ottawa and of pertinent government documents.

4. Gwendoline Pilkington

6. University of Toronto, Ontario Institute for Studies in Education.

7. Higher Education Group, University of Toronto

8. July 1972

9. April 1974

\section{III _- L'université et l'économie}

1. Université, perspective économique

2. Revue des différentes questions sur l'université avec applications à la situation québécoise. 
3. Revue de littérature scientifique avec intégration des données des universités du Québec.

4. Jean-Luc Migué, E.N.A.P. 31 Mont-Carmel, Québec 4.

5. Gérard Bélanger, Dépt. d'Économique, Université Laval, Québec.

6. Ecole nationale d'administration publique, 31 Mont-Carmel, Québec 4.

7. Conseil des universités de la province de Québec.

8. Avril 1972

9. Juin 1973

10. Les résultats peuvent être obtenus de/seront publiés dans différentes revues.

\section{IV - Curriculum and Teaching}

1. Committee to Investigate Teaching

2. To gather and digest information on various aspects of university teaching and learning from both inside and outside the university; to make this readily available to members of the university community; to encourage both innovation and research into teaching and learning by members of the academic staff.

3. A wide variety of survey techniques will be employed to gather data on teaching and learning, such as literature research, questionnaires, personal interviews, course guide evaluations, etc.

4. Dr. Wm. Meloff - D. Otto

5. Judy Brunt - Dave English - André Gareau

6. University of Alberta

7. C.I.T. and Institutional Research \& Planning

8. April 1970

9. Ongoing project

10. David Otto, IRAP. A list of projects with their descriptions, may be obtained from IRAP (David Otto). Reports will be available at the discretion of the Committee to Investigate Teaching. Requests for reports can be forwarded through D. Otto.

\section{IV-Curriculum and Teaching}

1. An Analysis of Home Economics Programs in Ontario Universities Based on the Development of Four Theoretical Patterns.

2. To provide a theoretical framework for analyzing and comparing the types of programs in Home Economics offered at Ontario universities. To correlate the type of program with enrolment and occupations selected by graduates. 
3. Definition of the four theoretical patterns on the bases of subject content. Classification and analysis of programs in Ontario universities. Acquisition of enrolment data from the universities. Acquisition of occupational data through a questionnaire sent to graduates. Analysis and interpretation of the relationships between the theoretical patterns, program subject content, occupational selection and enrolment.

4. Mary Jean Woods

5. None

6. University of Toronto

7. Higher Education Group

8. March 1971

9. March 1972

10. Interlibrary Loan, University of Toronto

11. M.A. thesis

IV - Curriculum and Teaching

1. Teaching in the Universities : No One Way

2. Edward F. Sheffield. Editor.

6. University of Toronto

9. To be published early in 1974 .

10. McGill-Queen's University Press.

11. Twenty-four professors, identified by their former students as excellent teachers, present highly personal accounts of their views of teaching and their ways of going about it. Among them they represent twenty-one disciplines and nineteen Canadian universities from Memorial in Newfoundland to the University of British Columbia. Nineteen of them teach and have written their accounts in English, five in French.

Though they differ greatly in personality and in the methods they use, they share the conviction that the teacher's role is to stimulate students to learn; every one is enthusiastic about his field of study; most of them rely on the lecture to present their material; all work hard at teaching - spending much time in preparation. They believe students are important.

In addition to summarizing the views and practices of the contributors, the editor analyzes the responses made by the thousand graduates who commented on professors they remembered as good teachers, The ten most-mentioned characteristics of these men and women are that they are masters of their subjects; deliver well-prepared orderly lectures; relate their subjects to life; encourage 
students' questions and opinions ; are enthusiastic about their subjects ; are approachable, friendly available; are concerned for their students' progress and welfare; have a sense of humour; are warm, kind, sympathetic; and use teaching aids effectively. As the editor points out, this list is not surprising.

What is more likely to be surprising is that graduates who studied in different fields at different times and under different conditions report similar patterns of effective teaching as they experienced it.

The editor concludes that effective teaching is more a matter of attitude (toward the subject and toward students) than of method. He believes that the improvement of teaching in the universities would be encouraged if the system of reward - rank, recognition and income - were altered so that it would compensate professors for devoting effort to teaching as well as to research and publication. He suggests that university teachers should be helped to understand how students learn and how best to help them learn, and that students could contribute to this understanding.

\section{IV - Curriculum and Teaching}

1. Approaches (mostly elsewhere) to the Improvement of Teaching in Higher Education.

4. Edward F. Sheffield

6. University of Toronto

9. Winter 1973

10. To be published in Improving Colleges and University, XXI, 1

11. By "elsewhere" I mean outside the United States and Canada. Most readers of this journal will be familiar with the programs that are under way in North America, but much more is going on in some other part of the world. These notes are based on information gathered during a series of visits between mid-1971 and mid-1972.

\section{The United States}

In may 1971 a conference on instructional development agencies in higher education was held at Michigan State University. Of the 16 institutions represented, a dozen were American universities with units devoted to the improvement of university teaching. Data in the conference report ${ }^{1}$ indicate that in their work these give highest priority to the provision of consultation services, short courses and workships for university departments and faculty members. These activities are followed in order of priorities by research and development projects with respect to curriculum and instruction, and the teaching of undergraduate and graduate students about aspects of teaching and learning. 
The prototype of the American instructional development agency may be said to be the Center for Research on Learning and Teaching of the University of Michigan. In a review entitled "Ten Years at CRLT"' ${ }^{2}$ the five basic activities of the Center are listed as consultation, funding projects for instructional experimentation, evaluation of the impact of instructional arragements, dissemination of information (notably by way of a periodical Memo to the Faculty), and research and development with respect to university teaching.

I have referred so far to general programs, university-wide in their scope. One must not overlook the work going on in professional, especially medical, education. In 1971 there 22 American medical schools with instructional developeducation. In 1971 there were 22 American medical schools with instructional development units, and another 20 hoping to establish such units. ${ }^{3}$

There may be much more to report about programs in the USA if and when the work of the Project to Improve College Teaching (sponsored from 1969 to 1971 by the American Association of University Professors and the Association of American Colleges) bears fruit. Readers will be aware, no doubt, of the three main reports prepared in this connection by Kenneth E. Eble: The Recognition and Evaluation of Teaching, Career Development of the Effective College Teacher and Professors as Teachers. ${ }^{4}$ Eble favors student evaluation of teaching, conscious preparation of graduate students for teaching their subjects, systematic though informal in-service staff development programs (orientation of the beginning teacher, career development in the middle years, and attention to the problems of those nearing retirement), the recognition of good teaching in promotion procedures, and improvement of the conditions in and under which teaching and learning take place.

\section{Canada}

In Canada the first program to mention is that of the Centre for Learning and Development at McGill University. Begun in 1969 on the model of the CRLT of the University of Michigan, the McGill Centre publishes a newsletter, Learning and Development; offers consultation to individuals and groups of faculty, students and administrators on a wide range of instructional problems; engages in cooperation with faculty members, in the design and development of instructional materials and methods; conducts and encourages research; aids in the evaluation of teaching and learning; and conducts workshops and conferences on topics of interest to university teachers. Like the Michigan Center, it has a fund from which grants are made to university departments and individual teachers to encourage innovation and experiment in curricula and instruction.

Functions somewhat similar to those of McGill program have been outlined for the Service de pédagogie universitaire of Laval University and the Service 
pédagogique of the University of Montreal, both of which were created in 1972. Several other Canadian universities and a good many, perhaps most, community colleges have institutional programs for the improvement of teaching, and many others have, or have had recently, committees looking into the possibilities.

There are several system-wide plans too. The Ontario Institute for Studies in Education offers an informal course for community college teachers in collaboration with a number of colleges of applied arts and technology in the Toronto area. The Faculty of Education of McGill University plans in 1973 to begin a program of training leading to certification for teachers in the English-language Cegeps (community colleges) of the Province of Quebec, and the network of Cegeps (collèges d'enseignement général et professionnel) in the Province of Quebec is served by a program of teacher evaluation called PERPE in French, SPOT (Students' Perceptions of Teachers) in English. By the time this report is read it is likely that, in addition, a Programme for Instructional Development will have been launched for the universities of the Province of Ontario - a scheme providing government grants in support of proposed projects designed to bring about innovation or improvement in university instruction. ${ }^{5}$ This plan is an outcome of a report on Television and Technology in University Teaching prepared for the Council of Ontario Universities and the provincial Committee on University Affairs by Bernard Trotter in $1970 .{ }^{~ " T h e ~ f i r s t ~ s e q u e l ~ w a s ~ a ~ w e e k-l o n g ~ c o n f e r e n c e ~ i n ~} 1971$ on "teaching university biological sciences," a pilot experiment of the kind which might be undertaken for many disciplines as part of the Programme for Instructional Development. ?

On a Canada-wide basis, both the Canadian Association of University Teachers and the Association of Universities and Colleges of Canada have committees at work on aspects of teaching and learning.

\section{Australia}

As early as 1962 it was possible to list a number of teacher training enterprises in Australian universities - a "tertiary education" option in the Diploma in Education course at the University of Western Australia and plans for a similar venture to start at the University of New England in 1964 (it did) ; short, intensive courses for university teachers at Queensland and Sydney; and short courses plus consulting service and programs of research into teaching and learning at Melbourne and New South Wales. 8

The National Union of Australian University Students is active in the distribution of documents designed to encourage staff to improve their teaching. Another source of encouragement is the Australian Vice-Chancellors' Committee which has a Steering Committee on Research and Experiment into Education Matters (SCREEM). As a result of SCREEM's efforts the AV-CC has established 
a Research Information Office, publishes an Education Newsletter to share experiences, and makes grants in aid of teaching experiments in the universities. Almost every Australian university now has or is about to have a center for research and development to serve these interests.

One of the most highly developed of the Australian university units is the Centre for the Study of Higher Education at the University of Melbourne. The service it makes available to university staff include :

- Discussion of teaching with members of staff - the preparation and presentation of material.

- Education communication - consultation, planning and production assistance for audio-visual aids: films, closed circuit television programs, synchronized tapeslide programs, carrels, student response systems, etc., etc.

- Course evaluation - assistance in planning, implementing and assessing student evaluations.

- Courses of induction and in-service teacher preparation - a "full course" entailing one week full-time followed by fortnightly seminars and individual tutorials; also other shorter courses.

- Principles and techniques of examining - collaboration with interested departments.

Two characteristics of this Centre are worthy of special note: its services are available on request, not actively promoted; and its staff members are engaged in action research, in collaboration with members of teaching departments, as well as in the provision of the services outlined above. ${ }^{9}$ This emphasis on research is to be found in several of the Australian units and is revealed in their names, e.g. the Tertiary Education Research Unit of the University of New South Wales and the Higher Education Unit of Monash University. As indicated above, research is the focus of the AV-CC's interest as well.

The Australian colleges of advanced education are active too. They are coordinated by a Commonwealth Advisory Committee on Advanced Education which in 1966 recommended as "highly desirable that all lecturers receive training in educational methods." The New South Wales Institute of Technology, as one example, requires "all new lecturing staff who have no previous teaching expe. rience to undertake an appropriate course in educational method." The course occupies two two-hour periods weekly for one semester, during which time the lecturer's teaching load is reduced.

\section{Britain}

Soon after its founding in 1964 the (British) Society for Research into Higher Education (SRHE) formed a Working Party on Teaching Methods which 
has been responsible for the preparation and publication of a series of monographs beginning in 1967 with the first edition of Ruth Beard's survey of Research into Teaching Methods in Higher Education. ${ }^{10}$ In a "letter of guidance" to the universities in 1969, the University Grants Committee (UGC) mentioned that it expected them to arrange for the training of their teaching staff. In the following year the SRHE and the (British) Association of University Teachers (AUT) held a conference on the training of university teachers. It became evident there that the UGC's letter of guidance was having observable effects and it was agreed that the SRHE should compile a record of the programs for the training provided by the universities for their teaching staff. The resulting report revealed that most universities were offering some such training, the most typical scheme being a one-week induction course for new lecturers, prior to their first term of teaching. ${ }^{11}$ Attendance is normally voluntary, but in a few institutions (the University of Glasgow is one) it is required.

Further encouragement of action is provided by the UGC, the Committee of Vice-Chancellors and Principals of United Kingdom Universities (CVC) and the AUT. They established a joint working group on the training of university teachers which the following is a brief summary:

- An induction course of two or three days provided by the lecturer's own university.

- An initial course of training (either a continuing course extending over several terms or a concentrated course lasting about two weeks) usually provided on a regional basis, for which staff should be allowed adequate time. It was suggested that such course be subject-area oriented.

- An advanced course or courses of about a week's duration (after three to seven years of service) provided on a regional or national basis.

- A specialist course or courses, for senior members of staff involved in providing continuing assistance for new teachers or in advising on developments in teaching and learning in higher education.

- A co-ordinating committee, representative of the CVC, the UGC and the AUT, to monitor the scheme. (It has been formed.)

In the meantime, in 1972 the UGC made grants totalling $£ 130,000$ to support 19 research projects in the training of teachers and administrators at twenty British universities. ${ }^{12}$

Perhaps the most extensive of the current provisions in British universities is that of the University Teaching Methods Unit of the University of London Institute of Education. Begun in 1965, its stress is on research and publication but it engages also in consultation with staff and departments and in the provision of short courses and conferences. It is customary for the Unit to organize a course 
for about 200 new lecturer in the autumn, a conference for 100 to 300 senior staff on some topic of general interest in January or April, and additional short courses or study groups throughout the academic year. During the year 1972.73 courses or study groups were offered on the design of experiments in education, effective speaking, student recruitment and selection, interviewing techniques, lecturing, the psychology of learning, small-group teaching, assessment, the philosophy of education, systematic approaches to the design of courses, and student cultures.

Like the Centre at Melbourne, the London Unit waits to be asked for assistance. Participation in activities is open to all members of the University staff, but is purely voluntary.

Britain's polytechnics, also, run staff development programs for their teachers. At the Hatfield Polytechnic, to cite one instance, new teachers are required to take an "in-service teacher training course" comprising 36 afternoon meetings held weekly throughout one academic year. The six "modules" of the course are: learning-teaching situations in relation to educational objectives, students, educational technology, assessment in education, further and higher education, and new ideas in education. Another example is offered by the Manchester Polytechnic which in 1972 formalized its program by establishing a Staff Development and Educational Research Unit.

\section{Some West European countries}

The notes in this section and the next are briefer and more personal reflecting glimpses during short visits.

The Netherlands. All 13 of the university level institutions in the Netherlands have pedagogical service units, employing a total of about 80 professionals, most of them psychologists. They tend to stress research and consultation rather than the provision of courses for teaching personnel. I visited two: the Center for Research on Higher Education (COWO) of the University of Amsterdam and the Institute for Educational Research and Development of the University of Utrecht. The latter, which I was told was the first in Holland, employs about 25 people, many of them seconded from the various disciplines represented in the University. The director mentioned particularly their work in curriculum planning. He said they had undertaken only one venture into training: a study group on group dynamics, which at least had the effect of improving communication among the participants, who were departmental colleagues.

The Federal Republic of Germany. A new national reform law, expected soon, will encourage steps forward improvement in instruction. It is proposed that each university should have a "center of didactics" attached to the central administration and responsible for the training of graduates involved in tutoring. According 
to my informant, these centers are likely to be manned from the regular disciplines rather than by specialists in pedagogy.

The University of Hamburg has pioneered in this field in West Germany. In 1970 it established an Interdisciplinary Center for Teaching Methods in Higher Education, staffed by people from a variety of disciplines, to undertake educational research and development, provide consultation and, as an outcome of performing these two functions, to engage in teaching about higher education. At the time of my visit early in 1972 they were engaged in experimental teaching projects (problem centered), work in curriculum development and evaluation with a number of faculties and departments, and short (two- to four-day) seminars on models for university reforms at the institute (department) or faculty level. A five-year experiment was about to be launched, making it obligatory for all "assistants" (potential professors) to receive training for teaching.

Denmark. The Institute for Studies in Higher Education at the University of Copenhagen offers a voluntary year-long course, better described as a workshop, which involves about a dozen university-level teachers several hours a week. After a general introduction to university teaching by the staff of the Institute, those in the group plan their own program. The Institute also offers short courses, on request, on such topics as examining, curriculum planning, small-group teaching and departmental budgeting.

Officers of the Danish Union of Students and the College of Rectors spoke well of the Institute's work.

Sweden. The Office of the Chancellor of the Swedish Universities has a Department of Educational Research and Development with three sub-divisions: one concerned with research (system and long-term studies), one with development (local research and experiment at the classroom level - the pedagogical service unit idea) and one with the in-service training of teachers in higher education. All three have funds for in-house studies and for grants in support of studies in the universities by university personnel. Reports on the projects of this Department are published in a series of bulletins now called Educational Development: Information on research and development in post-secondary education.

In 1971 the in-service training division announced a plan for the "pedagogical training of university teachers." It was to have three stages : a basic course of two weeks for all teaching members of staff in Swedish universities, a supplementary course of six weeks for at least one senior teacher from each department, and another supplementary course of four weeks for all department directors of studies. The plan would take five years to implement. ${ }^{13}$

When I was in Stockholm in the spring of 1972 the first actual course was in progress - a six-week program for 25 directors of studies from the universities, 
There was a two-week introductory period, just completed; then there were to be two weeks devoted to individual projects related to course development in the course members' own departments (to which they would return for that phase). These were to be followed by a regrouping for reporting and discussion and, some months later, by a follow-up session.

The chief of the in-service training division told me that in the current course he and his colleagues had intended that the emphasis should be on course objectives and course development rather than on teaching methods, techniques and styles, but the participants were much more interested in the latter. He said also that the 25 participants had been sub-divided into homogeneous discipline-groups but had re-formed into heterogeneous groups. He said it was planned to offer four courses for directors in 1973 and that it would probably be left to them to decide what they should organize by way of training experiences for teaching staff in their own departments. So what had originally been planned as a comprehensive and rather directive program had turned into a permissive scheme with a soft approach.

\section{The Soviet Union}

In 1966 a decree of the Supreme Soviet made it obligatory for every teacher in every higher education establishment in the Soviet Union to spend one term (four to five months) in each five-year period improving his qualifications as a teacher. (Furthermore, teachers in higher education must apply for re-appointment every five years).

As a result, there are "institutes" in the major centers to which teachers go from all over the country and from all types of higher education establishments universities, institutes and technicums. Each institute or course groups teachers of a single discipline (e.g. physics, biology, economics) and is held where there is strength in that discipline and where the country's experts are accessible. Stress is placed on extending and modernizing knowledge of the subject, with secondary but not minor emphasis on how to teach it. For the latter, experts in pedagogics are called on for some assistance. ${ }^{14,15}$

The University of Novosibirsk offers some of these institutes, as do the universities of Kiev and Leningrad, and when I was at the University of Moscow in September 1971 I was told that there were some 700 people there on such upgrading courses each term. In the Ministry of Higher and Specialized Secondary Education in Moscow there is a department called methodology (meaning curriculum ?) which is concerned with teaching method and the improvement of the qualifications of teachers. 


\section{Still other countries}

In New Zealand there are tentative beginnings, and $I$ understand there are interesting schemes in some other countries, for example, Poland, Mexico and several countries in South America, but I have no details about them. I have heard, too, of some countries in which practically nothing of this sort is going on. These include Japan, Belgium, Switzerland, France, Portugal, Spain and Italy.

\section{Conclusion}

In these approaches to the improvement of teaching there are variations with respect to many aspects :

- Initiative - may come from the students' union (local or national), the teachers' association (local or national), the local university senate or administration, a national government agency, or a combination of two or more of these.

- Emphasis - may be on one or more of research, publication, dissemination of information, consultation, projects (with funding), or courses (mostly short).

- Grouping of participants - may be across disciplines or by individual disciplines.

- Scope - either pedagogical service units in individual institutions or a systemwide program, or both.

- Location (in the case of a pedagogical service unit) - in the department of psychology, the faculty of education, the audio-visual center, the office of the president or the academic vice-president, or in a particular department or faculty as, for example, a school of medicine.

- Staff engaged in offering services - psychologists, educationists, or persons representing the range of academic disciplines in which teaching is done, i.e. specialists in the process of teaching and learning or specialists in the subjects being studied.

- Reception by teachers - surprisingly good in some settings, lukewarm or frigid in others. On the whole there seems to be greater receptivity in professional and applied fields than in arts and pure science.

I might have made more reference to student evaluation of courses and teaching as an approach to the improvement of teaching. This is an indeed relevant, although it is more a revelation of the need for improvement than a program for improvement. Course evaluation or assessment has a long history in some American universities and is spreading to others. It is becoming fairly common in Canada and Australia, but seems not to have been accepted in any general way in Britain or continental Europe.

There is evidence that where programs for the improvement of teaching exist they are used by a minority, but a growing minority, of staff. It is understandably 
difficult to find measures of success in achieving the ultimate objective: better teaching.

At the risk of being merely controversial rather than presenting a documented evaluation, I find myself wondering if the schemes to which attention has been drawn do not tend towards overemphasis on "research," much of it on too small a scale to be significant and much of it of the reinvention-of-the-wheel variety. I think, too, that many of the programs dwell overmuch on techniques and technology, and on experimentation and innovation - as if only the new were worthy. The alternative, for my taste, would be more stress on understanding the process of learning, the role of the teacher as an accomplice, and the attitudes, especially that of caring, which are at the heart of good teaching.

\section{References}

1. Alexander Lawrence T., and Yelon, Stephen L., eds., Instructional Development Agencies in Higher Education. East Lansing, Michigan: Michigan State University, Educational Development Program, Learning Service, 1972.

2. Erickson, Stanford C., ed., "Ten Years at CRLT," Memo to the Faculty (Ann Arbor, Michigan: University of Michigan, Center for Research in Learning and Teaching), No. 49, September 1972.

3. Alexander and Yelon, Instructional Development Agencies in Higher Education, p. 79.

4. Eble, Kenneth E., The Recognition and Evaluation of Teaching. Salt Lake City, Utah : Project to Improve College Teaching, 1970. Distributed by the American Association of University Professors, One Dupont Circle, Washington, D.C. 20036.

- Career Development of the Effective College Teacher. [Salt Lake City, Utah: Project to Improve College Teachers], 1971. Distributed by the American Association of University Professors.

5. Council of Ontario Universities, Montbly Review, IV, 2 (November 1972), 3.

6. Trotter, Bernard, Television and Technology in University Teacbing. A report to the Committee on University Affairs, and the Committce of Presidents of Universities of Ontario, 1970. Available from the Council of Ontario Universities, 102 Bloor Street West, Toronto, Ontario, M5S 1M8, or the Information Branch of the Ministry of Colleges and Universities, Mowat Block, 900 Bay Strect, Toronto, Ontario.

7. Good, Harold M., and Trotter, Bernard, eds., Frontiers in Course Development: System and Collaboration in Universily Teaching. Report of the Conference on Teaching University Biological Sciences, Jackson's Point, Ontario, May 1971. [Toronto, Ontario: Council of Ontario Universities, 1972.]

8. Cohen, S.W., "Teaching and Learning in Australian Universities," Australian Journal of Higher Education, I, 2 (November 1962), 75-88.

9. Falk, Barbara, "The Melbourne Approach to Teacher Training for University Staff," The Australian University, VIII, 1 (May 1970). 57-66.

10. Beard, Ruth M., and Bligh, Donald A., Research into Teaching Methods in Higher Education. 3rd edition. London: Society for Research into Higher Education, 1971.

11. Greenaway, Harriet, Training of University Teachers. A survey of its provision in univer- 
sities in the United Kingdom. London: Society for Research into Higher Education, 1971.

12. Britain, University Grants Committee, Annual Survey, Academic Year 1970-1971 (London: Her Majesty's Stationery Office, 1972. Cmnd. 4893), p. 8.

13. Sweden, Office of the Chancellor of the Swedish Universities, Department of Educational Research and Development, "Pedagogical Training of University Teachers," Research and Development in Post-Secondary Education, 1971: 11 (October 1971).

14. Burn, Barbara B., Higher Education in Nine Countries: A general report prepared for the Carnegie Commission on Higher Education (New York: McGraw-Hill, 1971), Chapter 10, "Higher Education in the Soviet Union," p. 300.

15. Ekgolm, Igor, "Higher Education in the Soviet Union" in Holmes, Brian, Scanlon, David C., and Niblett, W.R., eds., Higher Education in a Changing World: The World Year Book of Education 1971/72 (London: Evans Brothers, 1971), p. 294.

\section{IV - Curriculum and Teacbing}

1. A History of McMaster University, 1887-1957

2. To indicate, among other things, how a particular evangelical denomination (the Baptist) coped with the problem of higher education in Canada; what goals they set for themselves; the extent to which they achieved them; the role that personalities, theological doctrines, and issues such as 'fundamentalism' and 'modernism' played in the institution's growth; the extent to which the university responded to the educational needs of a rapidly changing society, etc.

4. C.M. Johnston

5. Two or three students have voluntered to work on aspects of the problem as part of their undergraduate assignments. Otherwise none.

6. McMaster University

7. McMaster University

8. 1967

9. Early 1973

\section{IV - Curriculum and Teaching}

1. The Development of a Physics Course Manual for Engineers and Physics Majors.

2. The object of this program is to establish a program of study that sets up the necessary definitions and procedures that will allow the student to solve problem sets in the laboratory and at the desk. Achievement levels are established through the use of weekly tests that determine the level that the student is operating at.

3. Since the student is able to see the precise work that he is responsible for, it is expected that a continuous study habit is developed. The fact that he knows his own progress and his own achievement level week by week, should have some motivational incentive into the program. 
4. Dr. A. Cone - Mr. F. Cook - Mr. R. Hamilton - Mrs. M. Modi Mr. T. Ryniak - Mr. S. Webster

6. Vancouver City College (Langara)

7. Vancouver City College

8. January 1972

9. January 1973

10. To be published in 1973 .

IV-Curriculum and Teaching

1. The Interaction of Student Variables and Media Efficiency in Teaching.

2. To more clearly outline the differences in student preferences and relative ability to to use effectively the different possible educational media in the ways these media are presently used; and to suggest other uses of these media.

3. A questionnaire is under development to elicit from students information on their media usage, both in and out of school ; media attitudes; personality data relating to media use; achievement, and motivation. Based on this questionnaire data, students will be divided into groups exposed to a series of learning units composed of similat information presented via differing media. Students will be exposed to "preferred" and "non-preferred" presentations. Attitude and achievement scales will form the dependent variables.

4. James H. Katz

5. Lionel Hunt

6. Loyola College of Montreal, Department of Psychology

7. Loyola College of Montreal

8. September 1971

9. June 1973

\section{IV_C Curiculum and Teaching}

1. Historical Studies of the University of Toronto

2. To mark the 150th anniversary of the granting of the University's charter by the collecting of detailed information about all aspects of the University's development since 1827 , and by the publication of a number of volumes dealing in various ways with the historical development of the University and its component elements.

3. Procedures are in the process of being developed by an Advisory Committee appointed by the President in April 1971.

4. Robin S. Harris 
5. To be appointed.

6. University of Toronto

7. University of Toronto

8. July 1, 1971.

9. December 31, 1977

10. University of Toronto Press

V-Professional Education

1. The Training of Administrators for Ontario Community Colleges.

2. A) To study the provisions, demand and need for preservice and inservice training of leaders and administrators in the CAATs of Ontario, and to develop from this information a proposal for a training program.

B) To provide a model for similar studies in other provinces and in the university systems.

3. The Delphi Technique of Reiterative Responses to Questionnaires.

4. G.H. Robertson

6. Florida State University and Sir Sandford Fleming CAAT, Peterborough, Ont.

7. a. Doctoral Fellowship from Canada Council

b. Sabbatical Leave from Sir Sandford Fleming College.

8. January 3, 1972

9. August 1973

\section{V-Professional Education}

1. A Study of the Learning, Understanding and Retention of Basic Economic Principles.

2. The purpose of the study is to examine learning among students in first year economic courses. The project is being carried out in the guise of a case study in the Department of Economics at Queen's University but there is some attempt

(1) to involve some other schools and

(2) to present the research findings in a way which will be of interest and value to economics departments in other institutions, both in Canada as well as in the United States, where similar research projects have been undertaken.

3. The method involves a test (developed by the principal investigators on the basis of a year's pre-testing and sampling) which is being applied over a three-year period to all students in the first year economics course and to a control group of students not taking the first year course. As well, the test will be applied at different 
dates to a sample of students in second and more advanced years who had previously taken the test in an effort to gauge the retention of basic principles.

4. Professors R.W. Crowley and D.A. Wilton, Department of Economics, Queen's University

5. Undergraduate research assistants

6. Queen's University

7. Ontario Department of University Affairs and Canada Council

8. May 1970

9. October 1974

10. The principal investigators, publication to be determined.

\section{$\mathrm{V}$ - Professional Education}

1. Physical Education - A Study of Professional Education in Ontario Universities.

2. The scope and purpose of the study is to examine through an historical and current description and analysis of four schools of physical education in Ontario, the role of an emerging professional school in the context of traditional and contemporary views of the idea of the university.

3. Historical and comparative content analysis of documentary information. Analysis of structured interview material and questionnaire data.

4. Maureen $\mathrm{H}$. O'Bryan

6. University of Toronto, Ontario Institute for Studies in Education.

7. Higher Education Group, University of Toronto.

8. January, 1973

9. July, 1973

\section{$\mathrm{V}$ - Enseignement professionnel}

1. Élaboration, réalisation et évaluation d'un programme expérimental de formation des enseignants (niveau secondaire) centré sur l'étude de la discipline et l'analyse de l'enseignement et de l'apprentissage (Projet Chicoutimi).

4. Dussault, G., A. Leduc et C. Pineault

6. Université Laval

7. Direction générale de l'enseignement supérieur et Université du Québec à Chicoutimi (UQAC)

8. 1969

9. 1974 


\section{IX - Student and Student Services}

1. Retention Rates

2. Historical analysis of promotion, transfer, and withdrawal rates at the faculty level to serve as parameters in an institutional enrolment projection model.

3. Computer analysis of historical records to determine cohort survival ratios by faculty and level of study.

4. K.W. Coull

6. University of Alberta

7. Institutional Research \& Planning

8. October 1970

10. K.W. Coull, IRAP

\section{IX - Student and Student Services}

1. Students' Attitudes : A Cross-cultural Study

2. Discover patterns of belief and attitudes in student-teachers in England, Canada, U.S.A and other countries and relate those to cultural differences and to their training programs, where possible.

4. Iohn McLeish

6. University of Alberta, Edmonton

8. September 1964

9. 1973

10. John McLeish ; published in various monographs.

\section{$\mathrm{X}$ - The Professor}

1. Fitness Evaluation of Faculty Members at the University of New Brunswick.

2. To appraise the present status of physical fitness of faculty members and to provide a comprehensive conditioning and exercise program.

3. A sub-maximal test of cardio-respiratory fitness to be administered to all faculty members at particular intervals during the university year.

4. Prof. Wm. MacGillivary - Prof. G.B. Thompson

5. Prof. Blake Ferris - Prof. Barrie Ward

6. University of New Brunswick

7. Faculty Research Grants Committee

8. October 23, 1972

9. April 30, 1973

10. Research Grants Committee or Principal Investigators. 
$\mathrm{XI}$ - Non-Degree Granting Institutions

1. The Planning and Development of Grant Mac Ewan Community College : The First Two Years.

2. To describe and analyze the initiation and early development of a new community college, with particular reference to establishing "organizational character" (as defined by Selznick)

3. Documentary analysis - interview - participant observation.

4. Dr. R.G. McIntosh

5. Graduate students in the Department of Educational Administration, University of Alberta.

6. University of Alberta

7. College Administration Project, Department of Educational Administration, University of Alberta.

8. April 1970

9. December 1972

10. College Administration Project Working Paper. 